\title{
Environmental Analysis and Zoning for an Urban Park Management Purpose
}

\author{
Elisabete Maria Zanin ${ }^{1 *}$, José Eduardo dos Santos ${ }^{2}$ and Carlos Henke-Oliveira ${ }^{2}$ \\ ${ }^{I}$ Depto de Ciências Biológicas; URI - Campus de Erechim; Av. 7 de Setembro, 162; 99700-000; Erechim - RS - \\ Brazil. ${ }^{2}$ PPG-ERN/UFSCar; Universidade Federal de São Carlos; Rodovia Washington Luís, Km 235; C. P. 676; \\ 13565-905; São Carlos - SP - Brasil
}

\begin{abstract}
Environmental analysis and zoning were carried out for management purpose of the Longines Malinowski Municipal Park (LMMP). With an area of 24.85 ha, this urban park includes a patch of sub-tropical humid forest, completely surrounded by residential and commercial areas in the City of Erechim, Rio Grande do Sul State,Brazil. Landscape features derived from aerophotogrametric maps, based on the use of Geographical Information Systems (GIS-IDRISI), resulted in several thematic maps, through which a proposal of environmental zoning was perfomed, observing the definition of five zones of use. The environmental diagnosis identified several types of activities potentially harmful to the biodiversity of the LMMP and city's environmental quality. The implementation of a management plan would be essential to maintain and preseve this urban park, aiming to ensure its participation in the urban quality of life.
\end{abstract}

Key words: Urban green area, quality of life, GIS

\section{INTRODUCTION}

Green areas have become a fundamental element of urban landscapes. Squares and urban parks occupy restricted areas in the cities, and are considered like a public utility. Initially, these green areas were related only with aesthetic and climatic aspects, but slowly started having a more expressive meaning with the recognition of their ecosystem services, mainly associated with air filtration, microclimate regulation, rainwater drainage, noise reduction, and recreational and cultural values (Bolund and Hunhammar, 1999; Oliveira et al., 1999; Sudha and Ravindranath, 2000).

The maintenance and increase in the number of green areas is one of the strategies to improve the quality-of-life in urban areas. However, establishing the minimum ratio value of square meters of green area per inhabitant is still a very controversial question. The National Association of Recreation from USA suggests that this ratio should be between 28 and $40 \mathrm{~m}^{2}$.inhabitants ${ }^{-1}$ (Milano, 1990), while the World Health Organization suggests the minimum value of 9 $\mathrm{m}^{2}$.inhabitants $\mathrm{s}^{-1}$, to be adopted as a base for the urban development in Latin America and Caribe (IDB, 1997). These values are suggested to be in the range of $13 \mathrm{~m}^{2}$.inhabitants ${ }^{-1}$ in higher population density areas and $12 \mathrm{~m}^{2}$.inhabitants ${ }^{-1}$ in less populated ones, also considering that for each 50,000 inhabitants there shall be one urban park of

\footnotetext{
Author for correspondence
} 
at least 40 hectares, thus determining a ratio value of about $8 \mathrm{~m}^{2}$.inhabitant ${ }^{-1}$ (Minas Gerais, 1991).

The environmental zoning proposals of natural and urban landscapes management units have been done based on scientific and technical criteria which consider: the identification of landscape sub-units within and on its surrounding; the identification of key-species that are important for the ecosystem structure or those of special aesthetic or ecological meaning; and the identification of strategies related with administration programs and the implementation of monitoring system, in order to evaluate the efficiency of environmental zoning. Most of these proposals are available to the landscape management units represented by the watersheds (Missio et al., 2000; Pires and Santos, 1995; Pires et al., 2000b) and natural conservation areas (Feliciano et al., 2000; Costa et al., 2000; Pires et al., 2000a). Few studies have been conducted in urban parks, since the implementation of this kind of green area doesn't concern about the biodiversity conservation. They are planned without involving a multi-disciplinary team and created to be an intensive recreational and leisure area, which only implies the installation of equipment, without proposing an environmental zoning. In Brazil, urban parks have not been considered in the land-use planning regarding urban landscape projects. Comprehensive information of vegetation in cities is lacking. Understanding the relation among urban green areas, people, and the environment can facilitate future urban designs that might enhance environmental and social benefits from urban tree cover (Nowak et al., 1996).

Erechim City has a varied ecological structure related to green areas ranging from: selected cultivars along avenues (377); squares (36), and one urban park, the Longines Malinowski Municipal Park (LMMP) (Zanin, 2002). The purposes of this study were the environmental characterization and zoning of the LMMP, and its immediate surrounding, subsidizing the development of actions related to its management plan to ensure its participation in the urban quality of life.

\section{MATERIALS AND METHODS}

\section{Study area}

The study area encompassed the Longines Malinowski Municipal Park (LMMP), located in
Erechim county (RS, Brazil). The park lies between the latitudinal parallels of $27^{\circ} 37^{\prime} \mathrm{S}$ and $27^{\circ} 38^{\prime} \mathrm{S}$ and the longitudinal parallels of $52^{\circ} 16^{\prime} \mathrm{W}$ and $52^{\circ}$ $17^{\prime} \mathrm{W}$ (Fig. 1a). Erechim is located in the north region of Rio Grande do Sul (Brazil). It comprises an area of 4,194 ha and a population of approximately 82,000 inhabitants. The climate is classified as mesothermal whith annual temperature average of $18^{\circ} \mathrm{C}$, rains $\left(1,400 \mathrm{~mm}\right.$.year $\left.{ }^{-1}\right)$ are spread throughout the year with no properly dry season (Zanin, 2002). The LMMP is an urban landscape feature of reference and orientation for the inhabitants of Erechim City. With an area of 24.85 ha it corresponds to a typical patch of the sub-tropical humid forest, completely surrounded by residential and commercial areas, and gives Erechim its peculiar character (Fig. 1b).

\section{Methodology}

For environmental analysis of the LMMP and its immediate surrounding, 51 aerophotogrametric maps (1:2000), based on aerial photographs of October, 1989 of the district of Erechim (RS) were used; another 9 aerophotogrametric maps (1:5000) of Erechim city and one topographic map (1:2000) of the LMMP, were also used for data upgrading. All these maps were digitized using GIS/CARTA LINX 1.2 software. The software GIS/IDRISI32 was used to process and analyze the geo-referenced digital data after a conversion from vectorial to grid based formats. Primary and derived data were related to hydrographic, hypsometric, clinographical and land use thematic maps of the study area. The clinographical map was obtained from a Digital Elevation Model, derived from the hypsometrical map. The current land use classes of the LMMP were based on photointerpretation (feature color, size, form, pattern and association) of one non-georefered aerial photograph (1:10000), one 2000 aerophotogrametric map $(1: 2000)$ and field observation. GIS/MAPINFO v.5.2 was used to perform the final edition of the thematic maps.

As a strategy to fulfill the requirements established by the Municipal Law 3,110 of November 30, 1998, regarding the creation of the LMMP, its area was divided in zones. This environmental zoning proposal was based on application of the following procedures: 1) mapping of the landscape environmental characteristics; 2) delimitation of the 
landscape sub-units; 3) description of species with higher ecological meaning present in the urban park; and 4) identification of risks and threats potentially harmful to the biodiversity and environmental quality of the urban park.

The environmental analysis based on combination of thematic maps, biological characteristics and legal principles allowed to establish criteria to identify homogeneous areas (zones) and its guidelines on the LMMP and its suroundings. Such criteria included cover land, anthropic structures, slope values, natural potential and limitations and types of uses (restricted, intensive, extensive and special uses). The surrounding zones were identified based on their specific biotopes and physical structures, with direct and indirect possibilities of public use control, as well as the developing administration programs for such zones. The objectives and guidelines predicted in the zoning system for National Parks (Decree 84,017, of September $\left.21^{\text {st }}, 1979\right)$ and the Conservation Units National System (Law 9,985, of July $8^{\text {st }}, 2000$ ) were also used in the LMMP environmental zoning purpose.

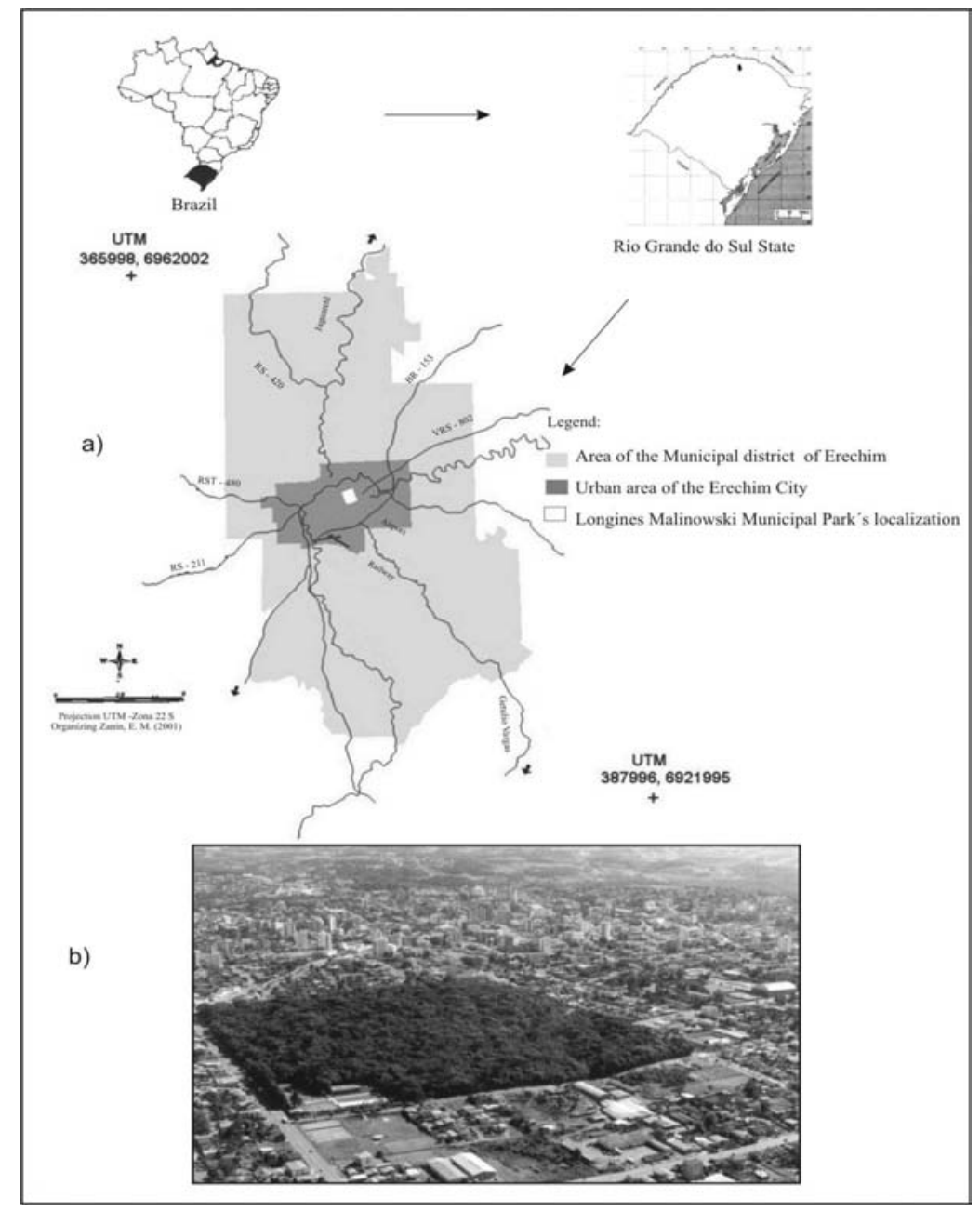

Figure 1 - a) Geographical localization of Longines Malinowski Municipal Park (LMMP), Erechim City, Rio Grande do Sul State, Brazil; b) Aerial view of the LMMP and immediate surrounding. Photo: Zardo (1999).

\section{RESULTS AND DISCUSSION}

The LMMP geo-referenced database elaborated with the thematic maps facilitated the urban park management. Through spatial analysis we were able to identify landscape features, which were 
available for a continuous monitoring. Such features included surface area, perimeter, structural elements and zones. The LMMP is located in Lajeado Banhado watershed (Fig. 2a), with an area of $248.453 \mathrm{~m}^{2}$ and drainage density of $14.76 \mathrm{~m} \cdot \mathrm{ha}^{-}$

1. This urban park has its river network restricted to a creek with approximately $170 \mathrm{~m}$, which crosses all the park area. The LMMP has elevations ranging from 730 to $775 \mathrm{~m}$, while the surrounding range from 615 to $825 \mathrm{~m}$ (Fig. 2b). Five slope classes were defined: a flat surface covering $2.1 \%$ of the urban park total area; a slightly rugged surface (30.4\%); a moderately rugged surface $(36.3 \%)$; a rugged surface $(25.2 \%)$, and a strongly rugged surface in $(6 \%)$ (Fig. 2c). Most of the LMMP area $\left(170.863 \mathrm{~m}^{2}\right)$ is associated with a flat surface to moderate rugged surface, where slope values range between 0 to $13 \%$, with minor potential risks of soil erosion, where simple conservation practices are proposed. However, there are one area of $77.590 \mathrm{~m}^{2}$ with rugged and strongly rugged surface, with slope values higher than $13 \%$ and a higher soil erosion risk, concerning the establishment of qualitative and quantitative rules for possible activities to be developed in the urban Park (Zanin et al., 2000).

Fourteen land use types were identified for the LMMP (Fig. 2d). The LMMP's greatest area $(68.80 \%)$ was covered by sub-tropical humid forest, followed by degraded sub-tropical humid forest $(20.6 \%)$ and 1.692 ha occupied by the physical area of Piscina Club. Information based on historical analysis of the LMMP showed that the physical area precariously granted in 1947 to the Piscina Club has increased about 16 times its original size in the last years. The park present a variety of biotopes with a large number of ecological niches (Fig. 2d), which were occupied by many different species of fauna, e.g. birds (Zanin and Santos, 2002a; Zanin, 2002), and trees. This would increase biodiversity, and should also be accounted for as a recreational value.

Phytosociological data of the LMMP sub-tropical humid forest's area revealed a Shannon and Weaver index value of 3.68. The floristics data showed the presence of 104 species, 78 genera and 42 families. Araucaria angustifolia (Bert) Kuntze, Maytenus ilicifolia Mart and Ilex dumosa Reiis were the most important species, and were included in the list of extinction threatened species in the
State of Rio Grande do Sul. The first two species were placed inside the vulnerable category and the third one in the rare category. This confirmed the importance of conserving this urban green area (Zanin and Santos, 2002a; Zanin, 2002).

The LMMP, being a subtropical humid forested area (known as "araucaria" forest), has been considered as a landmark by Erechim citizens. The presence of this expressive forested area characterized by arboreal individual of the species A. angustifolia (Bert) Kuntze that reach about 35 $\mathrm{m}$, strongly contributed to this attitude, as well as to the historical and ecological meaning of the LMMP (Zanin and Santos, 2002a; Zanin, 2002).

The process of urban development brings a threat to green areas. In Erechim city, green areas occupied 44.4 ha, $1 \%$ of the total urban area, and an average green areas value of $3.72 \mathrm{~m}^{2}$.inhabitant ${ }^{-1}$ (Zanin, 2002; Zanin and Santos, 2002b). This value was considerably lower than the observed in most other brazilian cities (Oliveira et al., 1999). Moreover, the LMMP accounted for $46 \%$ of this value.

The knowledge of specific natural attributes of LMMP as well its biodiversity risks and characteristics of its public use allowed to purpose five locally contextualized zones: Natural Zone of Restricted Use, Natural Zone of Extensive Use, Zone of Special Use, Recovery Zone and Zone of Intensive Recreational Use. Two immediate surrounding zones were also proposed (Fig. 3). These zones and its respectives administration guidelines are summarized in Table 1. Such guiderlines are related to the control of selective wood extraction, remotion of exotic species, deactivation of secondary trails and stimulation for the use of principal ones, creation of visitor's center, museum, and other structures, proposition of studies based on efficiency of trails as an environmental educational strategy, environmental awareness and carry capacity, among others actions (Table 1).

The frequent deterioration of the LMMP has been a problem for the city administration of Erechim being often associated with the lack of land use planning, and the community that does not get involved. Several types of risks to the LMMP biodiversity were identified as a result of its relationship with surrounding communities. Besides, actions shall be developed to increase 
public awareness about the problems involving the surrounding zone of the LMMP as a deposit for garbage and/or rests exotic species that are slash from residential gardens of the area in question (Zanin, 2002; Zanin and Santos, 2002a). As Erechim is expected to grow in the coming decades, it is important that the ecosystem services in LMMP are understood and valued by city planners and political decision-makers. A major challenge would be to understand the factors that determine the structure and composition of species assemblage in the LMMP. Such understanding would greatly enhance the ability to preserve ecological diversity in the area.

Erechim urban environment presents many constraints on green areas structure that managers and planners must considerer. However, it is clear that LMMP ecosystem services have a substantial impact on the quality of life in these urban area, and should be addressed in land-use planning. Decision making regarding this land use planning should aim to conserve and integrate the park within the urban landscape and to involve the implementation of environmental zoning plan. However, there are some factors acting in the opposite direction, which are related to: financial limitations of the public sectors; non-existence of a management plan and environmental policy to make decisions regarding the environmental issues; and lack of integration between the available scientific knowledge and the decisionmakers. Any initiative to improve the environmental quality of the LMMP will necessarily depend on the commitment and participation of the community. 


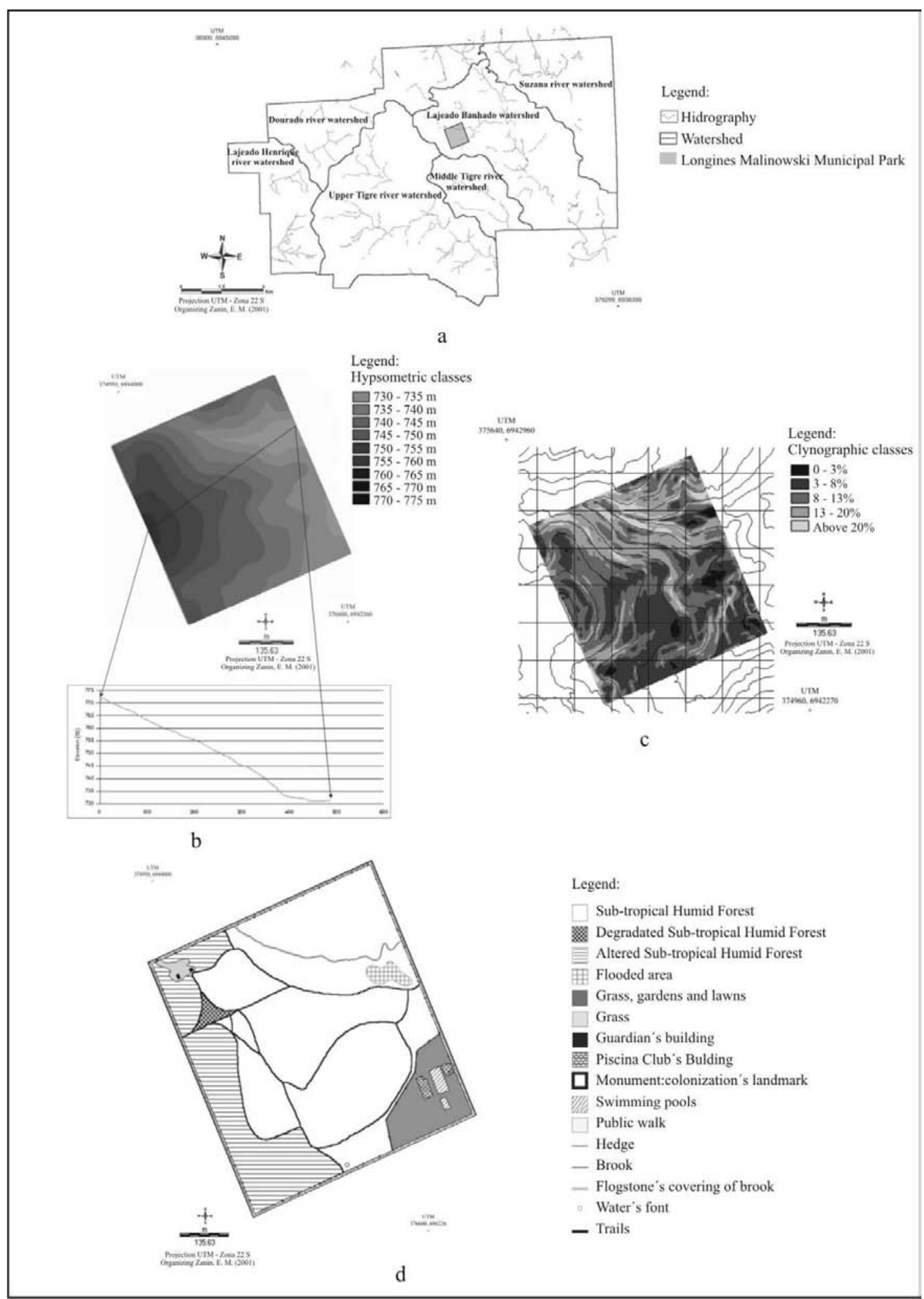

Figure 2 - a) Watershed limits of the Erechim City indicating the Longines Malinowski Municipal Park's localization; b) Digital Elevation Mode (DEM) and topographical profile of Longines Malinowski Municipal Park; c) Clinographic map of Longines Malinowski Municipal Park; d) Land use types of the Longines Malinowski Municipal Park. 


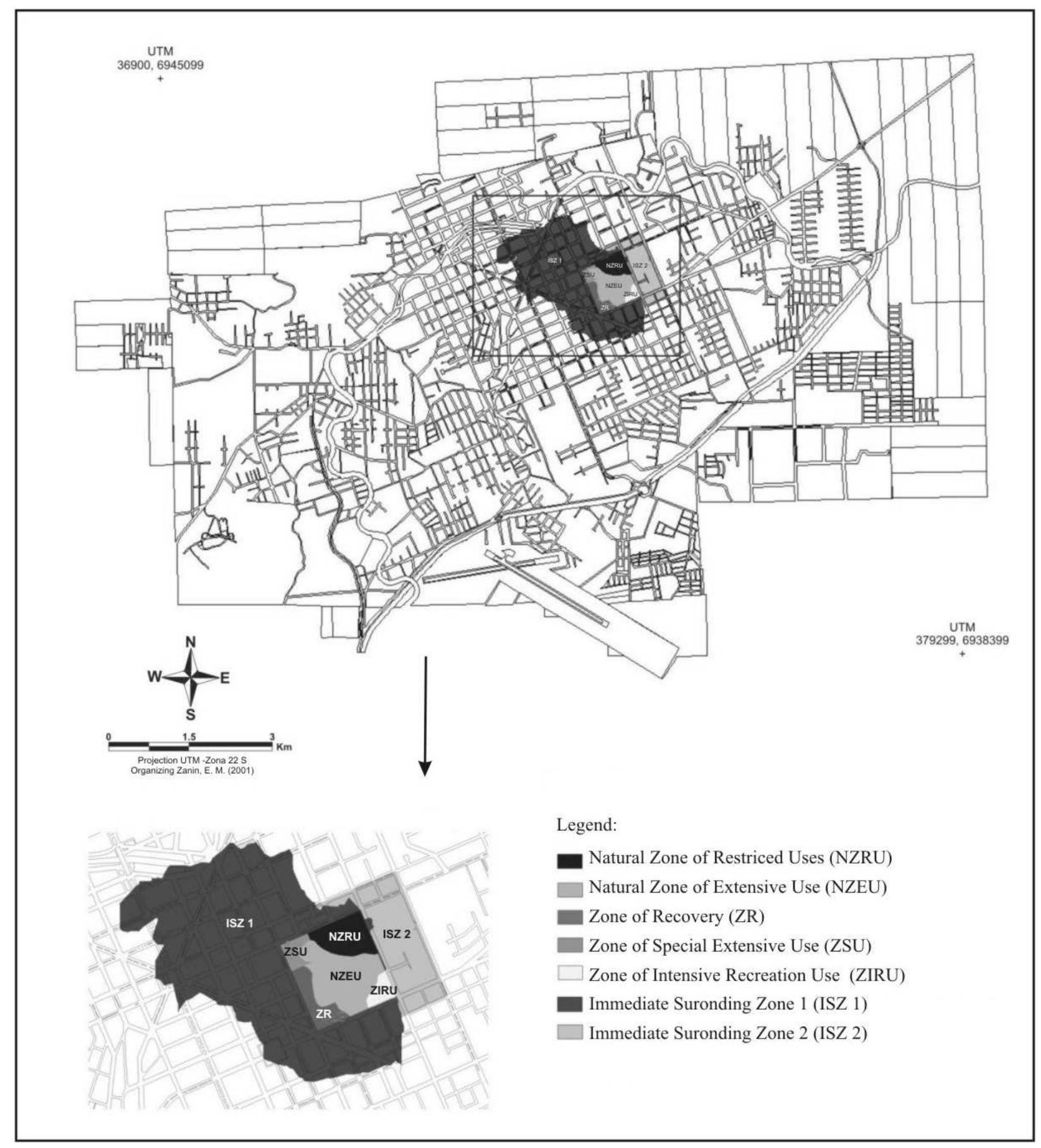

Figure 3 - Enviromental Zoning Proposal for the Longines Malinowski Municipal Park and its immediate surrounding. 
Table 1 - Summary of the environmental zoning proposal and administration guidelines zones for the Longines Malinowski Municipal Park (LMMP), Erechim City, Rio Grande do Sul State.

Natural Zone of Restricted Uses (NZRU). Total area: 5.63 ha, equivalent to $22.66 \%$ of the LMMP's total area, occupied by sub-tropical humid forest, with arboreal extinction threatened species in the State of Rio Grande do Sul. This Zone has the smallest degree of human intervention.

Administration Guidelines: occupation just for research activities and conservation of extinction threatened species; permanent inspection; prohibition of visits.

Natural Zone of Extensive Use (NZEU). It is equivalent to 48.81\% of the LMMP's total area; occupied by subtropical humid forest, with arboreal extinction threatened species in the State of Rio Grande do Sul. It shows human intervention associated with the selective extraction of wood in the past, intensive use of trails. Nowadays, the abandoned secondary trails show vestiges of vegetation recovery.

Administration Guidelines: occupation toward to environmental educational and research activities; deactivation of secondary trails; improvement of main trails with the implementation of a rain-water-drainage system; implementation of interpretative trails; permanent inspection; studies based on efficiency of trails, environmental awareness and carry capacity; implementation of garbage baskets.

Zone of Special Use (ZSU). Total area of 1.70 ha, corresponding to 6.84\% of the LMMP's total area, and occupied by the administrative structure.The existing constructions need to be done up. This area includes a degraded sub-tropical humid forest area, besides a monument regarding the colonization in such region.

Administration Guidelines: occupation directed to the LMMP's administration activities; permanent inspection; a visitor's center, a museum and a portico shall be built; implementation of signals to guide the visitors on how they should proceed; removal of exotic species; recovery of degraded sub-tropical humid forest; permanent and rotational expositions on historical and natural aspects of the LMMP.

Zone of Recovery (ZR). It occupies $14.89 \%$ of the LMMP's total area. A transitory zone with degraded subtropical humid forest that needs a management plan involving its arboreal community recovery.

Administration Guidelines: occupation directed to research activities; permanent inspection; removal of exotic species; recovery of degraded forest area.

Zone of Intensive Recreational Use (ZIRU). It represents 6.80\% of the LMMP's total area, irregularly occupied by a private club, with installations of pools, buildings and green area with leisure and recreation equipment. This zone shall be reintegrated into the LMMP and become an area of effective public use.

Administration Guidelines: creation of a Sport and Recreational Community Center; permanent inspection; implementation of recreational and sport activities included in the city's scheduled events.

Immediate Surrounding Zone 1 (ISZ 1). It corresponds to 116.23 ha of the urban area of the LMMP's surrounding; it is the drainage area of the upstream portion of Lajeado Banhado. Several stations of supply and services (eg. gas station, automobile maintenance and other urban services) are installed in this Zone, developing potential harmful activities of residue generation, and of permissible use according to the Municipal Plan for Urban Development. According to the zoning law for the urban area, it is compulsory to adopt treatment systems that determine the implementation of devices that separate oily residues, and subsequently revise the Municipal Plan to regulate these activities that are potentially harmful to the LMMP. In the squares surrounding the LMMP, educational actions shall be implemented, since this area is used as a deposit of garbage and/or residue of exotic species pruning from the residential gardens .

Administration Guidelines: residential and commercial activities; regulation of anthropic activities; non-formal environmental education activities; permanent inspection.

Immediate Surrounding Zone 2 (ISZ 2). It corresponds to 19.31 ha of the LMMP's East side area.

Administration Guidelines: residential and commercial activities; regulation of anthropic activities; non-formal environmental education activities; permanent inspection.

\section{RESUMO}

Foram realizados a análise e o zoneamento ambiental com a finalidade do manejo do Parque Municipal Longines Malinowski (PMLM). Com 24,85 ha, este parque urbano inclui um fragmento de floresta sub-tropical úmida, completamente cercado por áreas residenciais e comerciais na cidade de Erechim, Rio Grande do Sul. As características da paisagem, obtidas de cartas aerofotogramétricas, com base no uso de Sistemas de Informações Geográficas (SIG-IDRISI), resultaram 
em diversas cartas temáticas, pelas quais foi efetuada uma proposta do zoneamento ambiental, observando a definição de cinco zonas de uso. $\mathrm{O}$ diagnóstico ambiental identificou diversos tipos de atividades potencialmente prejudiciais à biodiversidade do PMLM e à qualidade ambiental da cidade. A implementação de um plano de manejo é essencial à manutenção e à conservação deste parque urbano, assegurando sua participação na qualidade de vida urbana.

\section{REFERENCES}

Bolund, P. and Hunhammar, S. (1999), Ecosystem services in urban areas. Ecological Economics. 29: 293 - 301.

Costa, S.S.M.; Santos, J.E.; Pires, J.S.R.; HenkeOliveira, C. and Moschini, L.E. (2000), Caracterização ambiental da Reserva Extrativista Chico Mendes (Acre, Brasil). In: Fórum Ecologia da Paisagem e Planejamento Ambiental. Rio Claro. SP, Anais... SEB: Rio Claro. São Paulo.CD-ROOM.

Feliciano, A.L.P.; Santos, J.E.; Pires, .JS.R.; Cavalheiro, F. and Moschini, L.E. (2000), Caracterização ambiental e proposta preliminar do zoneamento ambiental de uma Unidade de Conservação. (Estação Ecológica de São Carlos, Brotas, SP). In: Fórum Ecologia da Paisagem e Planejamento Ambiental. Rio Claro. SP, Anais...SEB: Rio Claro. São Paulo.CD-ROOM.

IDB (1997), Inter-American Development Bank. Good practices for urban greening. Washington: Environmental Division of social Programs and Sustainable development Department. 65pp.

Milano, M. S. (1990), Planejamento da arborização urbana: relações entre áreas verdes e ruas arborizadas. In: Encontro Brasileiro sobre Arborização Urbana. Curitiba. PR , Anais... SBAU: Curitiba. PR. pp.125-135.

MINAS GERAIS (1991), Manual de Arborização. Belo Horizonte. CEMIG: Superintendência de Comunicação Social e Representação -RP.22pp.

Missio, E.; Tonial, T.M.; Pires, J.S.R.; Santos, J.; Henke-Oliveira, C.; Rubert, C. and Moschini, L.E. (2000), Caracterização ambiental de unidades da paisagem da região Nordeste do Estado do Rio Grande do Sul. In: Fórum Ecologia da Paisagem e Planejamento Ambiental. Rio Claro. SP, Anais... . SEB: Rio Claro. São Paulo.CD-ROOM.

Nowak, D.J.; Rowntree R.A.; McPherson, E.G.; Sisinni, S.M.; Kerkmann, E.R. and Stevens, J.C. (1996), Measuring and analyzing urban tree cover. Landscape and Urban Planning. 36: 49-57.

Oliveira, C.H.; Santos, J.E. and Pires, J.S.R. (1999), Indicadores de arborização urbana da cidade de São Carlos (SP) com o uso do SIG-IDRISI. Brazilian Journal of Ecology. 3: 1-9.

Pires, J.S.R. and Santos, J.E. (1995), Bacias hidrográficas -Integração entre meio ambiente e desenvolvimento. Ciência Hoje. 40: 40-45.

Pires, A.M.Z.C.R.; Santos, J.E. and Pires, J.S.R. (2000a), Zoneamento ambiental e plano de manejo para uma unidade da paisagem. Estudo de caso: Estação Ecológica de Jataí e Estação Experimental de Luiz Antônio. In: Estudos Integrados em Ecossistemas. Estação Ecológica de Jataí , eds. Santos, J.E. and Pires, J.S.R., Rima. São Carlos. Vol. I.pp. 27-58.

Pires, J.S.R.;Santos, J.E. Pires and A.M.Z.C.R. (2000b), Análise de riscos ambientais no entorno de uma Unidade de Conservação (Estação Ecológica de Jataí, Luiz Antônio, SP). In: Estudos Integrados em Ecossistemas. Estação Ecológica de Jataí, eds. Santos, J.E and Pires, J.S.R., Rima. São Carlos. Vol. I. pp.7393.

Sudha, P. and Ravidranath, N.H. (2000), A study of Bangalore urban Forest. Landscape and Urban Planning. 47: $47-63$.

Zanin, E.M. (2002), Caracterização ambiental da paisagem urbana de Erechim e do Parque Municipal Longines Malinowski. Erechim, RS.163pp. Available in: <http://lapa.ufscar.br/banco de teses/ >

Zanin, E.M. and Santos, J.E. (2002a), Caracterização Ambiental de um Parque Urbano: Parque Municipal Longines Malinowski. Erechim, RS. Edifapes. Erechim. RS. 21 pp. Available in: 〈http://lapa.ufscar.br/public >

Zanin, E.M. and Santos, J.E. (2002b), Caracterização $e$ Diagnóstico Ambiental da Paisagem Urbana de Erechim, RS. Edifapes. Erechim. RS. 20 pp. Available in: 〈http://lapa.ufscar.br/public >

Zanin, E.M.;Santos, J.E.; Henke-Oliveira,C.;Pires, J.S.R. and Moschini, L.E. (2000), Caracterização Ambiental do Parque Municipal Longines Malinowski (Erechim,RS): subsídio ao plano de manejo. In: Fórum Ecologia da Paisagem. Rio Claro. SP, Anais... SEB: Rio Claro. São Paulo. CD-ROOM.

Received: April 22, 2003; Revised: May 25, 2004; Accepted: November 22, 2004. 